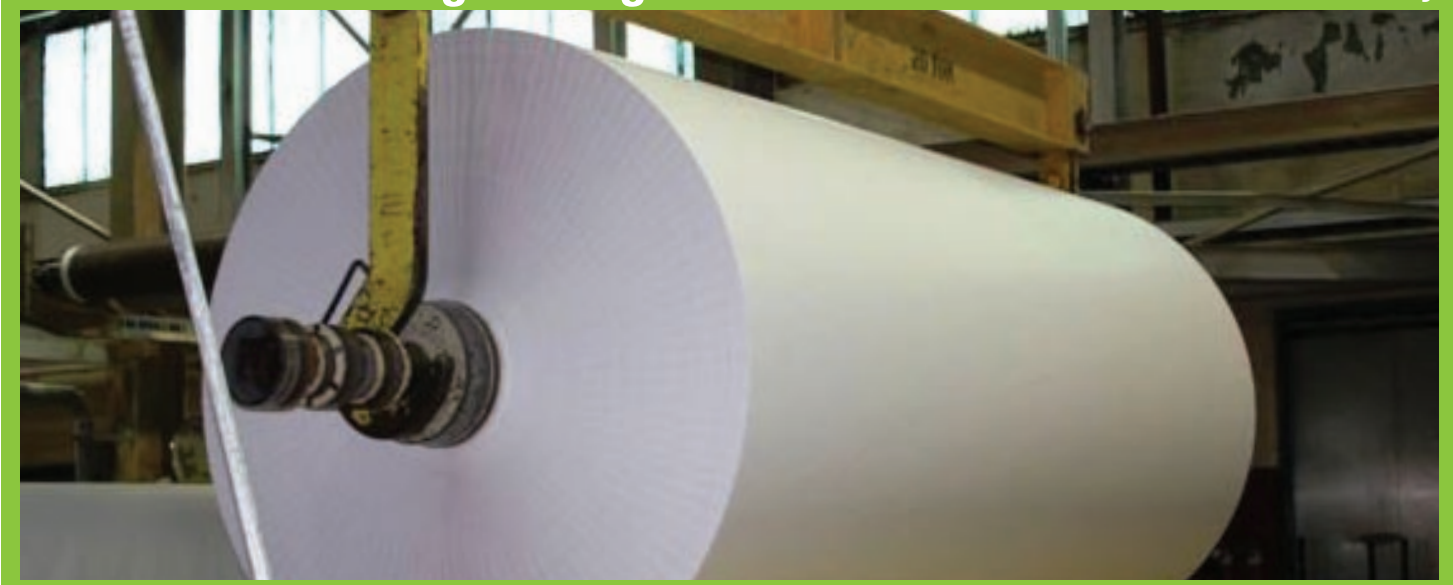

The Boise Inc. St. Helens mill produces nearly 1,000 tons of pulp and specialty paper per day, including a wide variety of light-to-heavy paper and napkin grade tissues.

\title{
Boise Inc. St. Helens Paper Mill Achieves Significant Fuel Savings
}

\section{Annual Energy Savings Exceed \$1 Million}

\section{Benefits}

- Achieved annual energy cost savings of more than $\$ 1$ million

- Achieved annual fuel savings of approximately 154,000 MMBtu

- Revealed innovative method to save energy

- Generated a simple payback of less than one month

\section{Key Findings}

- Boise Inc.'s St. Helens mill has a successful energy management program.

- The Save Energy Now assessment validated some projects that were being considered and uncovered additional savings opportunities.

- After the assessment the mill achieved significant fuel savings by reducing energy use of a parasitic load.

\section{Applications}

Steam systems are widespread in the pulp and paper industry and can account for a significant part of a paper mill's fuel consumption. Improving the efficiency of a paper mill's steam system can significantly reduce energy costs while maintaining reliability.

\begin{abstract}
Summary
In April 2006, Boise Inc. received a U.S. Department of Energy (DOE) Save Energy Now assessment at its pulp and paper mill in St. Helens, Oregon. The goal of the assessment was to evaluate and identify natural gas savings opportunities in the mill's steam system. The assessment was performed by DOE Energy Expert David Morgan of Akamai Energy LLC, who also provided training to the mill's employees on how to use DOE's suite of steam system software tools to identify energy savings opportunities.
\end{abstract}

Following the assessment, personnel at the mill took a strategic approach to the mill's steam system. The assessment validated some measures that were under consideration, such as lowering the oxygen $\left(\mathrm{O}_{2}\right)$ content on three boiler stacks and recovering waste heat from the whitewater process. Then, using some of the insights gained from the assessment, they identified and implemented a project that significantly reduced energy use by a process in the steam system. As a result, the mill achieved total savings of approximately $\$ 1$ million annually in energy costs and 154,000 MMBtu in fuel. With total implementation costs of $\$ 31,000$, the mill achieved a simple payback of less than one month. In addition, the results of the implementation of the mill's opportunities were shared with other Boise Inc. paper mills in the United States. 


\section{Project Drivers}

The St. Helens mill has a proactive energy management policy and participates actively in Oregon state-sponsored energy efficiency efforts. As a result, the mill's employees continuously strive to improve the energy efficiency of the mill's process, thermal, and motor-driven systems. The Save Energy Now assessment validated some opportunities that mill personnel had considered and helped them look at other process areas for ways the plant could reduce energy consumption. This led the mill's personnel to uncover an opportunity to reduce parasitic use of steam with significant energy savings potential.

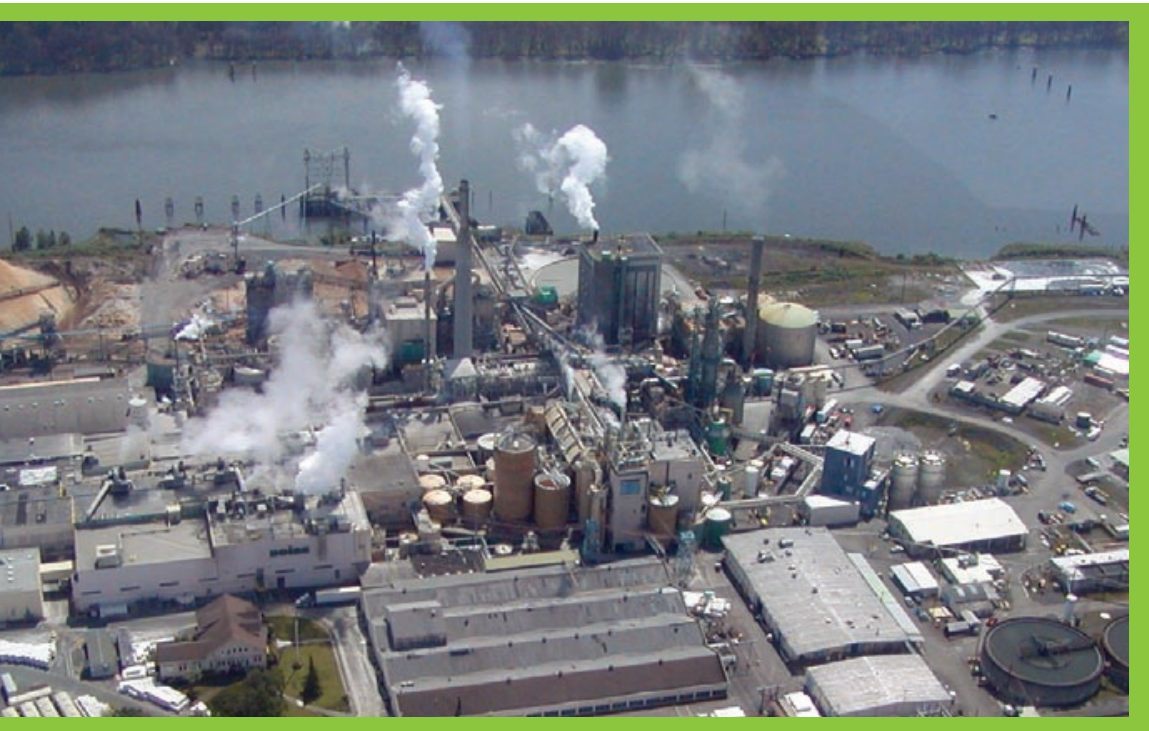

Aerial view of the Boise Inc. mill in St. Helens, Oregon.
Company and Plant Background

Headquartered in Boise, Idaho, Boise Inc. manufactures packaging products and papers including corrugated containers, containerboard, label and release and flexible packaging papers, imaging papers for the office and home, printing and converting papers, newsprint, and market pulp. In 2007, the Paper and Packaging businesses posted net sales of $\$ 2.4$ billion.

Boise Inc. operates five integrated pulp and paper mills, five corrugated products plants, a corrugated sheet plant, two distribution facilities, and a transportation business. The St. Helens mill employs 500 people and produces nearly 1,000 tons of pulp and specialty paper per day, including a wide variety of light-to-heavy weight paper and napkin-grade tissues. The mill's steam system is served by six boilers, including two Kraft recovery boilers that can run on black liquor and No. 6 fuel oil, and four dual-fuel package boilers that can operate on natural gas and No. 6 fuel oil. On average, the steam system generates more than $340,000 \mathrm{lbs} /$ hour, which is delivered in three pressure headers at 400, 235, and 50 psig, respectively. Steam is used to dry paper, create wood pulp, and help drive seven steam turbines.

The mill has a vigorous energy management program headed by a dedicated, full-time energy engineer supplemented by efforts from an employee energy team. Employees utilize a modern suite of process management tools to track and trend energy usage and performance metrics in real-time. All personnel have access to energy usage data and are encouraged to suggest ways to improve energy efficiency and production.

\section{Assessment Overview}

The Save Energy Now assessment at Boise Inc.'s St. Helens mill was sponsored by the DOE Industrial Technologies Program (ITP). It was conducted by an Energy Expert who formed an assessment team with several mill employees and installed DOE's steam system assessment tool (SSAT) software on their computers. The Energy Expert showed the team how to analyze plant data using SSAT and other steamrelated tools.

\section{Participating in a Save Energy Now assessment allowed us to evaluate energy savings opportunities in areas we had not previously considered. It validated the merits of some potential projects we had previously identified, and provided access to some valuable software-based tools that were useful in evaluating energy improvements."}




\section{Assessment Recommendations}

Using historical and current data, the assessment team identified potential energy-saving measures and evaluated each for technical and economic feasibility. After reviewing expected energy savings and the associated payback periods of near-, medium-, or long-term, the team determined the following 10 opportunities.

\section{Near-term opportunities}

- Modify Feedwater Heat Recovery Exchanger Using Boiler Blowdown-The mill had a heat exchanger that was out of service due to a malfunction. The assessment showed that if the heat exchanger was repaired and placed in service downstream from a condensate tank that served two boilers it would yield energy savings of almost 5,000 MMBtu and \$32,000 per year.

- Improve Boiler Efficiency - The stack $\mathrm{O}_{2}$ content for several of the package boilers was unnecessarily high. It was calculated that if the stack $\mathrm{O}_{2}$ content was lowered by an average of $0.5 \%$, it would result in annual energy and cost savings of 6,000 MMBtu and $\$ 40,000$.

- Increase Recovery Boiler Efficiency - The stack $\mathrm{O}_{2}$ content on a recovery boiler was also high. The assessment showed that this boiler's stack $\mathrm{O}_{2}$ content could be lowered by $2.1 \%$, which could yield energy and cost savings of 15,000 MMBtu and $\$ 104,000$ per year.

- Improve Insulation - The sloped underside of a blow tank serving the batch digesters was not insulated. Using DOE's 3E Plus ${ }^{\circledR}$ software tool, the team calculated how much insulation was needed to fully insulate the tanks. The assessment showed that insulating this section of the tank could yield energy savings of 1,500 MMBtu and save approximately $\$ 10,000$ per year.

- Recover Waste Heat from Wetlap WhitewaterWater from the whitewater process was being returned to the effluent stream without recovering the heat content. By modifying some of the mill's existing piping it would be possible to reuse the heat from the whitewater, resulting in estimated annual energy and cost savings of 3,000 MMBtu and $\$ 20,000$.

\section{Medium-term opportunities}

- Install Backpressure Steam Turbine Between High and Medium Pressure Headers - The mill currently uses a pressure reducing valve (PRV) to let 400 psig steam down into a 235 psig header. The assessment showed that if an extraction backpressure turbine generator was installed in place of the PRV it could generate approximately 7,000 kW for the plant. Although it would result in slightly greater fuel use, it would yield annual energy savings of approximately 62 million $\mathrm{kWh}$ and more than $\$ 1.6$ million.

\section{- Install Backpressure Steam Turbine Between} Medium and Low Pressure Headers - Installing a backpressure turbine generator in place of the PRV currently in service between the 235 and 50 psig headers would generate approximately $3,000 \mathrm{~kW}$. This would yield annual energy savings of approximately 27 million $\mathrm{kWh}$ and cost savings of more than $\$ 718,000$.

\section{- Preheat Water to Plant by Recovering Waste Heat} in Effluent Stream - The assessment showed that the recovery of heat from the effluent stream could enable the plant to preheat the water it draws from the Columbia River. Estimated annual energy and cost savings were 876,000 MMBtu and \$5.8 million.

\section{- Replace Yankee Dryer with Gas Turbine-On} behalf of an outside company, the mill operates a tissue machine that is served by a gas-fired Yankee dryer. The assessment suggested that the Yankee dryer could be replaced with a gas-fired combustion turbine generator, and the machine could use the gas turbine exhaust to heat the air supply required by the Yankee dryer. By removing the existing gas-fired dryer the mill would reduce electricity demand from the dryer's electric-driven fans by approximately 261 kW and save more than 207,000 MMBtu per year since the turbine generator would use less natural gas. At the same time, the gas turbine could generate approximately $1,200 \mathrm{~kW}$ for the mill. Annual cost savings were estimated at $\$ 2.1$ million.

\section{Long-term opportunities}

- Use Alternate Fuel-The assessment noted that if the mill were to install a hog fuel boiler annual fossil fuel consumption would be reduced by approximately $70 \%$. This opportunity was evaluated using a base case with natural gas at $\$ 6.80 / \mathrm{MMBtu}$, a boiler efficiency of approximately $81 \%$, and a steam header pressure of $235 \mathrm{psig}$. The hog fuel boiler assumptions included hog fuel at a Btu equivalent of $\$ 2.50$ / MMBtu, a hog fuel boiler efficiency of $65 \%$, and a 600 psig steam header. Based on these assumptions, the increase in hog fuel purchases was vastly offset by the decrease in natural gas consumption. The net estimated annual natural gas and cost savings were almost 3 million MMBtu and more than $\$ 9$ million.

If all the above opportunities were implemented, the total annual energy cost savings was estimated at more than $\$ 19$ million. 


\section{Results}

After carefully evaluating all of the energy efficiency opportunities identified by the assessment team, St. Helens mill personnel were able to implement a couple of the near-term measures right away. They lowered the package boiler stack $\mathrm{O}_{2}$ levels, and made some changes to the piping leading to the effluent stream in order to recover waste heat.

A team of mill personnel then re-examined various processes within the generation side of the mill's steam system and identified a new opportunity to reduce steam supplied to a parasitic load during periods when it was not providing any useful work. This led to a sharp reduction in steam usage by that load. In conjunction with other conservation activities this enabled the mill to shut down one of the package boilers. Annual energy savings from this project were approximately $147,000 \mathrm{MMBtu}$ and $\$ 984,000$.

Total annual energy savings from the implementation of some of the assessment recommendations plus the reduction in parasitic energy usage was nearly 154,000 MMBtu. This yielded annual natural gas cost savings of more than $\$ 1$ million. With total implementation costs of approximately $\$ 31,000$, the mill achieved a simple payback of less than one month. The other opportunities could not be implemented because of capital constraints and other legal and technical issues. However, information about the assessment and results of the savings opportunities were shared with other Boise Inc. mills.

\section{Lessons Learned}

Independent evaluations of industrial steam systems by outside experts can provide valuable insights that can lead to significant energy savings opportunities. At Boise Inc.'s mill in St. Helens, Oregon, employees are accustomed to independent feedback. The assessment by the DOE Energy Expert provided some additional insights into the energy usage patterns of mill's steam system. Later on, the mill's employees adopted a different approach toward evaluating steam usage that enabled them to uncover a new opportunity to reduce parasitic energy usage.

SSAT and other DOE software tools such as AIRMaster+, the Fan System Assessment Tool (FSAT), MotorMaster+, the Process Heating Assessment and Survey Tool (PHAST), the Pumping System Assessment Tool (PSAT), and 3E Plus can be used to analyze industrial systems and processes and generate energy efficiency opportunities.

\section{About Save Energy Now}

Through Save Energy Now, DOE's Industrial Technologies Program (ITP) helps industrial plants operate more efficiently and profitably by identifying ways to reduce energy use in key industrial process systems. Visit www.eere.energy.gov/industry/saveenergynow for more information.

\author{
A Strong Energy Portfolio for a Strong America \\ Energy efficiency and clean, renewable energy will mean a stronger economy, a cleaner environment, and greater \\ energy independence for America. Working with a wide array of state, community, industry, and university partners, the \\ U.S. Department of Energy's Office of Energy Efficiency and Renewable Energy invests in a diverse portfolio of energy \\ technologies.
}

For more information, contact the EERE Information Center, 1-877-EERE-INF (1-877-337-3463), www.eere.energy.gov And visit the DOE Industrial Technologies Program home page: www. eere.energy.gov/industry 